\title{
MAIN CHALLENGES AND OPPORTUNITIES FACED BY THE NONPROFIT SECTOR IN CURRENT POLAND
}

\author{
Agnieszka Rymsza \\ Korczak University, Poland
}

\begin{abstract}
There are over 100000 nonprofit organizations registered in Poland that constitute a growingly important actor in the economic area and for the public administration. The sector has been growing, yet there are many factors that distract nonprofit organizations from carrying out many of their missions and goals and from playing many of the important functions in a society that are or were expected from them. This paper presents the main challenges and opportunities faced by the nonprofit sector in Poland in the recent years and at the beginning of 2016 as well as both the negative and positive trends observed in its development. A stress will be put on the relations between nonprofit organizations and the government and the process of governmentalization will be described.
\end{abstract}

Keywords: governmentalization, Polish nonprofit organizations, Polish nonprofit sector.

\section{Introduction}

There are over 100000 nonprofit organizations registered in Poland that constitute a growingly important actor in the economic area and for the public administration. The nonprofit sector is more and more important economically, as it employs a growing number of citizens and is selling more and more services. It is also an increasingly important partner for public administration, as public institutions are contracting more and more public tasks to nonprofit organizations.

The sector has been growing, yet there are many factors that distract nonprofit organizations from carrying out many of their missions and goals and from playing many of the important functions in a society that are or were expected from them.

The aim of this paper is to present the main challenges and opportunities faced by the nonprofit sector in Poland in the recent years and at the beginning of 2016 as well as both the negative and positive trends observed in its development. The paper will analyze most important dimensions of the functioning of the nonprofit sector in Poland and the focus will be put on the relations between nonprofit organizations and the government, which is the most interesting and most threatening area for the identity of the nonprofit sector in Poland. At the end of the paper there will be presented the threats and hopes for 
the nonprofit sector connected with the new party in power after the presidential and parliamentary elections that took place in 2015.

The analysis that will be presented comes from the qualitative research of the Author (in-depth interviews with people working in the nonprofit organizations), the research in which the Author participated ${ }^{1}$, a review of the quantitative research on the Polish nonprofit sector done by others, knowledge gained at various conferences and seminars devoted to this topic, own experience of working in the Polish nonprofit sector and living in Poland, and, recently, opinions raised by nonprofit sector activists during numerous meetings with Government Plenipotentiary for Civil Society ${ }^{2}$ and reflection on the Author's observations.

\section{Legal environment}

The Polish nonprofit sector is mostly regulated by the Act on Public Benefit Activity and Voluntary Work, which was passed in 2003 and is often called the constitution of the third sector.

The passing of the Act was the first step out of the chaos prevalent since the political changes, although experts claim that some chaos accompanied the sector for many years on, in which both organizations and officials were learning the new law, which abounded in many ambiguous interpretations.

The most important dimension of the Act was that the Act made it compulsory for local governments to pass annual programs of cooperation with nonprofit organizations and gave them ability to outsource the realization of various public tasks to nonprofit organizations. The Act also divided the activity of nonprofit organizations into statutory unpaid, statutory paid and an economic activity. The novelty was the activity of statutory paid services for which organizations could charge fees without having to register economic activity ${ }^{3}$ as long as the salaries of people providing these services did not exceed a certain level.

The Act also introduced a status of public benefit organization. Organizations that receive this status can receive $1 \%$ of individual citizens' tax liabilities. Unfortunately, relatively few organizations benefit from the $1 \%$ mechanism. Although the percentage of citizens transferring $1 \%$ of the tax liabilities to public benefit organizations rose from less than 3\% in 2004 to $45 \%$ in 2014 (Ministry of Finances, 2005, 2015), funds from 1\% go in large part to

\footnotetext{
${ }^{1}$ For over 10 years I have been conducting every years experts' panels as part of Civil Society Organizations Sustainability Index research project, commissioned by the USAID and covering an increasing number of countries in Central and Eastern Europe, Asia, Africa and Middle East. See the bibliography for references.

${ }^{2}$ To which I have been an advisor since Jan. 2016 and I have been participated in those numerous consulting meetings.

${ }^{3}$ Which entails many additional duties and taxes and make it impossible to participate in certain public tenders.
} 
the so-called sub-accounts for individuals, run by just a few organizations ${ }^{4}$. Another problem with the $1 \%$ mechanism is that many citizens began to treat this $1 \%$ as a substitute for donations and stopped donating money to organizations.

Apart from the Act on Public Benefit Activity and Voluntary Work there are also an Act on Foundations and an Act on Associations ${ }^{5}$, which regulate some aspects of registration and other specific issues with regard to these two legal organizational forms.

As far as the registration of organizations in Poland is concerned, it is too complicated, lengthy and require from organizations submission of too many documents. Despite of common technical advancement it is still impossible to register an organization through the Internet. For the last several years there has been also a problem with finding 15 people required to register an association. Many people, not being able to find these 15 people, registered a foundation instead, even without any capital. In 2015 the Law on Associations was amended. Among the most important changes there was the decrease from 15 to 7 of the minimal number of people who can register an association, which might decrease the level of the mentioned pathology when many smaller groups with no capital instead of associations create a foundation, which in Poland do not require endowments. Other changes were: shortening of the time for consideration of the registration application to 7 days, abolition of supervision of the local government over the process of registration of an association. The Amendment in the Law on Associations limited thus the political control over the registration of an association (and thus political acceptance for the activities it wants to carry out). These changes concern only associations. It is still quite difficult to register a foundation. The procedure of registering a foundation remains bureaucratic, complicated, and lengthy, and is much more complex even from the procedure of registering of a limited liability company.

Another problem connected with the registration is that in Poland there is no obligation to deregister an organization which is not functioning anymore and nothing has been done in this regard. New organizations are registered every year and their absolute number has been growing. But also many stop functioning. Due to no obligation to deregister it is impossible to say how many out of over 100000 registered organizations in Poland are actually active and whether the number of active organizations has been growing or decreasing. It is estimated that around $70 \%$ of registered organizations are active.

\footnotetext{
${ }^{4}$ The idea of $1 \%$ mechanism was to support public benefit organizations. Instead, a few organizations created numerous sub-accounts, on which they collect the money from $1 \%$ and by taking a small amount to themselves they support the therapy of other needs of individual children.

${ }^{5}$ Act from April 6 ${ }^{\text {th }}, 1984$ on Foundations with later changes and Act from April $7^{\text {th }}, 1989$ on Associations with later changes.
} 
What remains problematic for nonprofits is that they still must submit reports to various institutions, each in a different format, which is burdensome, especially for smaller organizations. They also complain of numerous inspections, mostly from granting institutions, which can span ten to fifteen days per year and thus hinder organizations' activities. Such inspections generally focus on documentation and do not assess the extent to which granted money serves the public benefit. Internal management is not regulated, law is very superficial in this regard.

Nonprofits in Poland can legally sell products and services, either through economic activities if they are registered also as a business entity or by selling mission-related products or services to recover costs. Organizations can compete for government contracts at both the local and central levels, though engaging in business activities disqualifies organizations from the right to participate in some public bids. The public procurement system has social clauses that contractors must fulfill or receive more assessment points for, for instance, employing people with disabilities, the long-term unemployed, or youth. It gives nonprofits more chances to win a bid. On the other hand, organizations often have to have their own contribution (partly financial) to the realization of certain projects, which makes many of them unable to participate in bidding procedures. Most organizations prefer to apply for public funding than make their own money through commercial activities. More local authorities buy services from local nonprofits.

\section{Employees, volunteers and associations' members}

\section{Employers}

Although more and more Polish citizens work in the nonprofit sector, the Polish nonprofit sector is based on unpaid work performed by volunteers or associations' members. $45 \%$ of organizations do not have any paid employees, $35 \%$ have any paid employees (regardless of the type of employment contract) and only $20 \%$ of organizations have at least one employee on a regular permanent employment contract (Praca platna $i$ spoleczna, 2016). Employees of the nonprofit organizations more and more openly express their criticism over the fact that most of them have only project-based, short-term (and not permanent) contracts, and are forced to voluntary work which they do not want to perform. They debunk a myth that all nonprofits' employees work mostly for mission. It comes together with professionalization of the nonprofits and a new generation of people (today's young people are more assertive and less eager to work long hours for free). Young people treat the work for/in nonprofits as a regular paid-job and want a regular employment contract. In the opinions of organizations' leaders, main problems faced by the employees of Polish 
nonprofits are: too low wages (55\%), lack of promotion opportunities (47\%), too much work (45\%) and mentioned before lack of employment stability (34\%) (Praca ptatna i spoleczna, 2016). In 2015 a new labor union of nonprofit sector' employees came into being and one could notice the growth of the discussions (seminars, conferences) on the working conditions in the nonprofit organizations.

\section{Volunteers}

Opinions and data from various research about volunteering in Poland are ambiguous. It might depend on how volunteering is understood and on the type of questions asked in the research. For many it is only formal engagement in nonprofit organizations, while others consider as volunteering all types of social engagement without enumeration (such as helping sick neighbors or performing various activities at parishes).

According to research done by KLON/JAWOR Association, 20\% of Poles engage in volunteering (Wolontariusze $i$ czlonkowie, 2015) and this percentage has not been changing over several years. People who run volunteers' centers ${ }^{6}$ in Poland claim that more and more people come to their centers, willing to work for free for others. Some nonprofit sector's experts claim that it is more and more difficult for organizations to find volunteers as people more and more often engage in informal activities (like informal urban movements, often around particular actions) and not in formally registered organizations (which is also civic engagement and might in itself be considered also as a positive development), while according to others there might be more and more volunteers, especially among young people, who just seek work experience (in such cases volunteering is not truly voluntary but results from a high unemployment rate) ${ }^{7}$.

\section{Associations' members}

The membership of Polish associations has been decreasing for years (Wolontariusze $i$ członkowie, 2015). There are a few reasons for that.

One of them is that most associations typically do not try hard to seek new members. So called public benefit organizations ${ }^{8}$ seek support from citizens primarily during campaigns when they try to persuade citizens to designate 1 percent of their tax liabilities to their organization.

\footnotetext{
${ }^{6}$ Relations during the meeting of representatives of 8 volunteers' centers from various Polish cities with Government Plenipotentiary for Civil Society on Feb. 12, 2016.

${ }^{7}$ Civil Society Organizations Sustainability Index Research Panel, Institute of Public Affairs, Nov. $4^{\text {th }}, 2015$.

${ }^{8}$ Organizations with public benefit status that enables them to receive $1 \%$ of tax liabilities of the citizens. Among the conditions that have to be fulfilled to receive such a status there are: conducting of public benefit activities listed in the Act on Public Benefit Activity and Voluntary Work Such for at least 2 years and the functioning of the controlling body within an organization.
} 
Large membership organizations have also become smaller due to their focus on donors rather than on their members. They also rather look for professional employees, not unprofessional members or volunteers (professionalization of organizations). Big membership makes it also difficult to run an organization as it is difficult to find the time where the majority of members will be able to come to meet up and membership organizations make it necessary to consult the members on all important decisions. It is time consuming and slows down the process while often quick decisions have to be made. For this reason there are also more and more foundations registered in the recent years in comparison to associations, as foundations by definition and by law do not have members.

It also seems that fewer people want to be 'artificial members' who have no say in anything or are only 'on paper', in documents. As it was already mentioned, for many years the Law on Associations required 15 members to register an association and many people were members only because they were asked for it by their friends. Due to this requirement of a certain number of members to register an associations, in the recent years in Poland there has been a growing number of foundations registered, in comparison with associations (Wolontariusze $i$ czlonkowie, 2015). The capital necessary to register a foundation in Poland is very low. It amounts to 1000 PLN (around \$250). Indeed, there has been more and more difficult in recent years to find the required 15 people to create an association and, for this reason, with the amendment to the Law on Associations in 2015 the number of required members to register an association was decreased from 15 to 7 .

Among people who really want to make a difference there are also more and more of those who instead of joining the existing organizations where all roles are established prefer to create their own organizations or act informally. Indeed, informal movements and actions have been gaining popularity in recent years in Poland. Also so called participatory budgets (in which local citizens vote on projects listed on the website of the local authorities and local authorities fund the project with the highest number of the vote) are gaining more and more popularity.

\section{Public image}

Media coverage of nonprofit organizations in Poland is quite problematic ${ }^{9}$. It focuses on financial scandals involving organizations and large protests or events having an impact on politics, rather than the positive daily impact of

\footnotetext{
${ }^{9}$ Opinions expressed during Civil Society Organizations Sustainability Index Research Panel, Institute of Public Affairs, Nov. $4^{\text {th }}, 2015$.
} 
various activities of the nonprofit organizations. The only regular activities that receive routine coverage revolve around assistance to poor children or people with disabilities. Despite years of organizations' efforts to engage journalists in their work, the media remains unaware of much of the sector's work. Few journalists are interested in the activities of the nonprofits. On the other hand, nonprofits themselves do not use up the time on TV or radio available for them. From 2011 there has been a law obligating Polish National TV channels and the Polish National Radio to devote a certain amount of time every day (9 minutes) to the promotion of activities of organizations with public benefit status. Most organizations, however, do not know that they have such an opportunity or do not know how to prepare a TV spot. Moreover, it is very expensive to produce a social campaign spot and the free time is often available at night time.

The media coverage (focus on scandals) influences public perception of the nonprofit organizations. They are often perceived as interest groups, with their political and particular (also financial) interests as organizations, not organizations looking after social interest. $48 \%$ of Poles think that in nonprofit organizations funding is often misused and people act for their private interest ${ }^{10}$. More citizens seem to recognize the activities of nonprofit organizations, primarily those of charities and large organizations that receive national media coverage or are very active in the 1 percent campaigns. Few people, however, are aware of the diversity of the sector, differentiate between associations and foundations and know the term: nongovernmental organizations.

Nonprofit organizations are better and better at public relations and are actively creating their image. Thanks to the development of technologies and the Internet they can in a cheaper way promote their activities and they do so.

\section{Finances of nonprofit organizations}

The growing problem of nongovernmental organizations in Poland (even though the name would suggest otherwise) is their growing dependence on public funding.

Although $60 \%$ of organizations collect memberships' fees (Finanse organizacji pozarzqdowych, 2015), those fees are really low and do not constitute a significant value in money. In 2011 they constituted only $7 \%$ of the sector's income (Podstawowe fakty..., 2013).

Looking generally, the use of the already mentioned 1 percent mechanism an option for taxpayers to designate 1 percent of their tax obligations to an organization with public benefit status - has for years continued to increase. For the 2014 tax year, around 12.5 million individuals designated 557 million zloty

\footnotetext{
${ }^{10}$ Data received from the KLON/JAWOR Association's research team.
} 
(approximately $\$ 141$ million), around 50 million zloty more than in 2013, to the 7,888 organizations that are eligible for this support. At the same time, fewer organizations really benefit from this mechanism, as around $25 \%$ of the whole $1 \%$ money goes to one organization that runs 'subaccounts' to support particular children (Ministry of Finances, 2015). In this way, the mechanism that was to support organizations that serve public benefit became a mechanism to support private interests of individuals. The practice has been growing for years yet each consecutive government does not want to ban this practice, being afraid of big protests of parents of children with disabilities, for whom it is the only way to get funding for the expensive rehabilitation of their children.

Individual philanthropy continues to decrease, as many citizens consider the 1 percent mechanism to be a sufficient form of philanthropy. Some nonprofits have recently begun to use crowd funding to fund initiatives. Corporate philanthropy is largely focused on activities that will increase profits in the long-run by improving their image. As philanthropy remains limited, organizations focus more on seeking public grants. Organizations also prefer to rely on public funding rather than engage in risky commercial activities. More and more organizations, however, collect fees for their services (in a form of paid benefit activity to recuperate costs) than 3 years ago (growth from $45 \%$ to $55 \%)^{11}$. More nonprofits are aware that they can legally do that and openly collect fees for their services (some of them so far collected fees in the form of pseudo-donations). Some organizations started collecting fees due to shortage of funding. Most organizations collect membership fees, but such fees are small and do not provide significant revenue. For this reason, some organizations do not even bother collecting fees and instead use the time to prepare additional grant proposals for more significant amounts of funding.

The 2015 was a year of a break between the former and coming EU funding period, so many organizations had to look for temporary funding from other sources (while waiting for new EU grant competitions) yet still had to let go many employees, as they did not have funding necessary to keep them. There is a huge financial stratification in the sector, and the largest organizations get most available funding.

But the main source of funding for most organizations having any funding at all are, as mentioned before, money from public sources. Although the research shows that organizations point to more sources of funding they get funding from than it was the case 3 years ago (Finanse organizacji pozarzadowych, 2015) local governments have been the main source of funding for nonprofit organizations in Poland for years. For years nonprofits have

\footnotetext{
${ }^{11}$ Data received from the KLON/JAWOR Association's research team.
} 
become more and more dependent on public funding, which for many meant drifting from their original mission.

Most nonprofit organizations' funding from local authorities comes in the form of contracts for public services. The government does not allocate discretionary funding for nonprofits and thus organizations must do what governments tell them to do in the contracts.

\section{Relations between nonprofit organizations and public administration. Growing dependence on public funding and its impact on the loss of identity and drifting from the core mission}

The relations between nonprofit organizations and public administration in Poland are determined to a large degree by the process which the author calls the governmentalization of the nonprofit sector.

By the governmentalization of the nonprofit sector the author means the process, in which:

1) nonprofit (nongovernmental) organizations are becoming more and more dependent on contracts and projects funded by public institutions, as a result of which

2) they are adopting priorities and methods of operation of public institutions,

through which

3) they are becoming in fact quasi-public institutions (government extensions or quangos), causing

4) functional growth of government (and the weakening of functional importance of the nongovernmental sector) ${ }^{12}$.

Nonprofits in Poland are more and more dependent on public funding, as more and more organizations use public funding (in 2014, 55\% of organizations profited from local government funding and 18\% from central government funding, in comparison with, respectively, $48 \%$ and 12\% in 2011 (Finanse organizacji pozarzadowych, 2015). And such growing trends have been in place for years. Public funding has also constituted the growing part of the whole budget of the nonprofit sector (taken together, public funding from local and central government as well as the European Union constituted $30 \%$ of the whole nonprofit budget in 2003, $41 \%$ in $2005,52 \%$ in 2007, $44 \%$ in 2009 and $49 \%$ in 2011 (Podstawowe fakty..., 2013).

\footnotetext{
${ }^{12}$ Compare: A. Rymsza, Zagubiona tożsamość? Analiza porównawcza sektora pozarzqdowego w Polsce $i w$ Stanach Zjednoczonych, Ministry of Work and Social Policy, Warsaw 2013.
} 
Why does governmentalization of the nonprofit sector mean drifting from the core missions of organizations? Missions, values, social functions - different from functions of government and business sectors. It is in accordance with government failure theories, according to which the third sector came into being to be an alternative to the government (provide different services, for other target groups).

In the table below one can find exemplary manifestations of governmentalization of the nonprofit sector and its negative consequences

Table 1 Exemplary manifestations of governmentalization of the nonprofit sector and its negative consequences

\begin{tabular}{|c|c|}
\hline Manifestations of govenrmentalization & Consequences \\
\hline $\begin{array}{c}\text { Adjusting to government priorities } \\
\text { (regarding the type of beneficiaries, } \\
\text { services) through accepting government } \\
\text { programs }\end{array}$ & $\begin{array}{c}\text { Abandonment of people excluded from } \\
\text { government programs; services incompatible } \\
\text { with existing needs }\end{array}$ \\
\hline Dependence on public funding & $\begin{array}{c}\text { Abandonment of the civil society role of } \\
\text { checking government action (watchdog) }\end{array}$ \\
\hline $\begin{array}{c}\text { Maximalization of the number of } \\
\text { programs' beneficiaries and decreasing of } \\
\text { costs (quantitative indicators as a decisive } \\
\text { factor in competition for public funding) }\end{array}$ & $\begin{array}{c}\text { Quantity > quality } \\
\text { Minimal standards of care, support, } \\
\text { abandonment of service provision to difficult } \\
\text { and demanding beneficiaries (f.ex. people } \\
\text { with most severe disabilities) }\end{array}$ \\
\hline
\end{tabular}

Source: Author's construction

Thus, through governmentalization nonprofit organizations often abandon helping people excluded from government programs, restrain their criticism towards government authorities and agencies, especially from criticizing the bodies they receive or want to receive funding from and lower the standards of care. They stop serving as an alternative to the government sector. Thus the governmentalization of nonprofit (nongovernmental) organizations threatens the fulfilment of functions traditionally expected from nonprofit (nongovernmental) organizations. Through governmentalization nongovernmental organizations are ceasing to be nongovernmental.

What are the main reasons for growing dependence on public funding? The first reason is that organizations are trying to secure funding for financial stability and growth as philanthropy (corporate and individual), the only-typical for nonprofit - funding, turned out not to be a sufficient and reliable source of money. The second reason comes from the change in the character of support from the government, which is less discretionary and organizations have less say in how the funding they receive can be spent. 
Dependence on public funding is not the only dimension of the relations between nonprofit organizations and public administration. There are many organizations that engage in various advocacy and watchdog activities. But those coalitions work mostly on the central level and communicate with the central government, while organizations are mostly dependent on local funding.

\section{Threats and hopes for the nonprofit sector after the presidential and parliamentary elections in 2015}

From various international news on the situation in Poland at the end of 2015 and the beginning of the 2016, a person from abroad could get the impression that the Polish democracy has been vanishing. Since strong democracy is highly correlated with a sine qua non condition for the strong and vibrant nonprofit sector, one could think that the democratic roles of nonprofit organizations and regular citizens have been also vanishing in Poland.

The situation is much more complex and not as it seems at the first sight.

From the one hand, it is true that the government while passing certain acts at the beginning of its term omitted the consultation phase, during which citizens and organizations can comment on the laws' proposals ${ }^{13}$. It seems to assume that since they won the elections and got the majority of the vote, they are authorized by the society to make the reforms they announced in the campaign.

On the other hand, this is the first Polish government in Polish history that created the Office of the Government Plenipotentiary for Civil Society that aims at strengthening civil society in Poland. The Plenipotentiary was appointed on January $8^{\text {th }}, 2016$ and has a plan of several changes that are to reform and strengthen the nonprofit sector and civil society in Poland.

Among the changes the Plenipotentiary aims to implement ${ }^{14}$ there are:

- Creation of the Council of Social Dialogue, a council that is to be a place of a dialogue between the government and the nonprofit sector. The idea is that the nonprofit sector (its various sub-fields) is truly represented in the Council;

- $\quad$ Amendment of the Act on Public Benefit Organizations and Voluntary Work to make it more open for smaller and weaker organizations;

\footnotetext{
${ }^{13}$ In Poland all acts that are passed by the government should go through so-called consultation phase. This is regulated, among others, by such acts as: Act on central administration departments [Ustawa o działach administracji rządowej] from Sept. 4th, 1997, Ustawa o Radzie Ministrów from Aug. $8^{\text {th }}$, 1996, Act on labor unions [Ustawa o związkach zawodowych] from May 23rd, 1991 and Act on employers' organizations [Ustawa o organizacjach pracodawców] from May 23rd, 1991. The regulations allow the government to omit the consultation phase in 'exceptional situations' without really explaining what are these exceptional situations.

${ }^{14}$ They can be found at the Plenipotentiary website at: http://www.spoleczenstwoobywatelskie.gov.pl/programdla-rozwoju-spoleczenstwa-obywatelskiego [access Feb. 2016].
} 
- The change in support programs for the nonprofit sector run by the central government to prioritize the support for civic education, the watchdog, advocacy organizations and organizations that increase the social participation of citizens;

- Make more time (and in better hours) available for the nonprofit sector in public television and public radio;

- Creation of Polish Solidarity Corps of Volunteering that would encourage volunteering through giving long-term volunteers various benefits including participation in interesting meetings and trainings, free tickets to various cultural places, etc.

- Decrease of bureaucracy of nonprofit organizations, especially those smaller ones

- Introduction of small and large institutional grants for the development of organizations

In March 2016 the Office of Government Plenipotentiary for Civil Society organized a conference during which the Plenipotentiary presented its program for the nonprofit sector's reform and invited the nonprofit organizations to cooperation on its implementation.

These plans for the development of civil society in Poland sound very promising and are commonly accepted by most nonprofit organizations in Poland. The future will show how many of them will become a reality and how many obstacles to the development of the nonprofit sector in Poland will be combated.

\section{Conclusions}

The Polish nonprofit sector has been growing for years, yet there are many factors that distract nonprofit organizations from carrying out many of their missions and goals and from playing many of the important functions in a society that are or were expected from them.

Among the most important factors constraining its development one should list:

- Complicated and lengthy registration process

- Complicated reporting requirements and controls

- Unfriendly media coverage

- $\quad$ Short-term funding

- $\quad$ Requirement of own contribution to profit from public funding

- Dependence on public funding and governmentalization

These problems are known to the first in the Polish history and recently appointed Government Plenipotentiary for Civil Society who has a plan of several changes to reform and strengthen the nonprofit sector and civil society in 
Poland. The plans for the development of civil society in Poland sound very promising and are commonly accepted by most nonprofit organizations in Poland. The future will show how many of them will become a reality and how many obstacles to the development of the nonprofit sector in Poland will be combated.

\section{References}

Finanse organizacji pozarzadowych [Finances of the nonprofit organizations], 2015-12-29, written by the research team of the Klon/Jawor Association, http://www.fakty.ngo.pl/ wiadomosc/1889353.html [access: March 2016].

Ministry of Finances, Department of Income Taxes, (2015). Information on 1\% of tax liabilities from individuals passed to public benefit organizations in 2014, Warsaw.

Podstawowe fakty o organizacjach pozarzadowych. Raport z badania 2012 [Basic facts on nonprofit organizations. Report from the 2012 research] (2013). Warsaw: Stowarzyszenie Klon/Jawor.

Praca płatna $i$ spoleczna $w$ NGO [Paid and voluntary work in NGOs], 2016-02-15, written by the research team of the Klon/Jawor Association, http://fakty.ngo.pl/wiadomosc/ 1898753.html, [access: Feb. 2016].

Program dla rozwoju spoleczeństwa obywatelskiego [Program for the development of civil society], http://www.spoleczenstwoobywatelskie.gov.pl/program-dla-rozwoju-spolec zenstwa-obywatelskiego [access: Feb. 2016].

Ustawa z dn. 24 kwietnia 2003 r. o Działalności Pożytku Publicznego i o Wolotariacie z późn. $z m$. [Act from April $24^{\text {th }}, 2003$ on Public Benefit and Voluntary Work with later changes]

Ustawa $\mathrm{z}$ dn. 6 kwietnia 1984 r. o Fundacjach $z$ późn. zm. [Act from April 6 ${ }^{\text {th }}, 1984$ on Foundations with later changes]

Ustawa z dn. 7 kwietnia 1989: Prawo o Stowarzyszeniach z późn. zm. [Act from April $7^{\text {th }}$, 1989 on Associations with later changes]

Wolontariusze i czlonkowie [Volunteers and members], 2015-12-29, written by the research team of the Klon/Jawor Association, http://fakty.ngo.pl/wiadomosc/1889295.html, [access: Feb. 2016].

Rymsza, A. (Fall 2013). Eksperci o kondycji sektora pozarządowego w Polsce w latach 20042011 [Experts on the condition of the nonprofit sector in Poland in 2004-2011]. In: Kwartalnik Trzeci Sektor, Nr 30.

Rymsza, A. (Summer 2005). Partnerzy służby publicznej? Wyzwania współpracy sektora pozarządowego $\mathrm{z}$ administracją publiczną $\mathrm{w}$ świetle doświadczeń amerykańskich [Partners in public service? Challenges in the cooperation between nonprofit sector with public administration in the light of American experiences]. In: Kwartalnik Trzeci Sektor, Nr 3 .

Rymsza, A., „Poland”, in: The 2009 NGO Sustainability Index For Central and Eastern Europe and Eurasia, USAID, Washington, DC 2010, also available at: http://www.usaid.gov/locations/europe_eurasia/dem_gov/ngoindex/2009/poland.pdf, [access: 2010]

Rymsza, A. (2011). Poland. In: The 2010 NGO Sustainability Index For Central and Eastern Europe and Eurasia. Washington, DC: USAID. 
Rymsza, A. (2012). Poland. In: The 2011 NGO Sustainability Index For Central and Eastern Europe and Eurasia. Washington, DC: USAID, also available at: http://transition.usaid.gov/locations/europe_eurasia/dem_gov/ngoindex/reports/2011/20 11CSOSI_Index_complete.pdf, [access: 2012]

Rymsza, A. (2014). Poland. In: The 2013 NGO Sustainability Index For Central and Eastern Europe and Eurasia. Washington, DC USAID, also available at: http://www.usaid.gov/ sites/default/files/documents/1863/EE_2013_CSOSI_FullReport.pdf, [access: 2014]

Rymsza, A. (2013). Zagubiona tożsamość? Analiza porównawcza sektora pozarzqdowego $w$ Polsce $i w$ Stanach Zjednoczonych [Lost identity? The comparative analysis of the nonprofit sector in Poland and the United States]. Warsaw: Ministry of Work and Social Policy. 